\title{
Fetal Hind Limb Oxygen Consumption and Blood Flow during Acute Graded Hypoxia
}

\author{
DAVID W. BOYLE, KATHRYN HIRST, GARY O. ZERBE, GIACOMO MESCHIA, AND \\ RANDALL B. WILKENING \\ Division of Perinatal Medicine, Departments of Pediatrics, Biometrics, and Physiology, University of Colorado \\ School of Medicine, Denver, Colorado 80262
}

\begin{abstract}
Hind limb blood flow and $\mathrm{O}_{2}$ uptake, mean blood pressure, and heart rate were measured in six fetal sheep at 127-141 d gestation in the control state and at different levels of hypoxia that were induced by partial occlusion of the maternal terminal aorta. Blood flow was measured by an ultrasonic flow transducer. Control fetal arterial $\mathrm{O}_{2}$ content $\left(\left[\mathrm{O}_{2}\right]_{\mathrm{a}}\right)$ in the descending aorta was 3.25 $+0.17 \mathrm{mM}$. In response to graded acute hypoxia, blood flow first increased $\left(22.2\right.$ versus $19.9 \mathrm{~mL} \cdot \mathrm{min}^{-1} \cdot 100 \mathrm{~g}^{-1}$, $p=0.003)$ and then decreased abruptly at approximately $1.5 \mathrm{mM}\left[\mathrm{O}_{2}\right]_{\mathrm{a}} \cdot \mathrm{O}_{2}$ uptake decreased about $12 \%(14.74$ versus $16.71, p=0.03)$ as $\left[\mathrm{O}_{2}\right]_{\mathrm{a}}$ decreased to $1.5 \mathrm{mM}$, and then fell markedly, tending toward zero for $\left[\mathrm{O}_{2}\right]_{\mathrm{a}}=0.9$ $\mathrm{mM}$. In the 2.7- to $1.5-\mathrm{mM}\left[\mathrm{O}_{2}\right]_{\mathrm{a}}$ range, heart rate increased above control (194 versus $\left.169 \mathrm{~min}^{-1}, p=0.0024\right)$, whereas mean blood pressure did not change significantly. For $\left[\mathrm{O}_{2}\right]_{\mathrm{a}}$ $<1.5 \mathrm{mM}$, heart rate decreased to $148 \mathrm{~min}^{-1}(p=0.0005)$ and mean blood pressure increased above baseline (55 versus 47 torr, $p=0.0001$ ). In conjunction with previous evidence, these results define a state of acute moderate hypoxia in which the whole fetus can sustain a relatively high rate of oxidative metabolism, and a state of acute severe hypoxia $\left(\left[\mathrm{O}_{2}\right]_{\mathrm{a}}\right.$ between 1.5 and $\left.1.0 \mathrm{mM}\right)$ in which $\mathrm{O}_{2}$ uptake by some fetal organs is selectively and markedly decreased. (Pediatr Res 28: 94-100, 1990)
\end{abstract}

Abbreviation

$\left[\mathrm{O}_{2}\right]_{\mathrm{a}}$, fetal arterial $\mathrm{O}_{2}$ content

Under normal physiologic conditions, the $\mathrm{O}_{2}$ content and $\mathrm{PO}_{2}$ of fetal sheep arterial blood are approximately $3 \mathrm{mM}$ and 20 torr, respectively, in the descending aorta, and only slightly higher in the ascending aorta (1). Despite these low $\mathrm{O}_{2}$ content and $\mathrm{PO}_{2}$ values, it is now recognized that there is a range of fetal oxygenation over which oxygen consumption by different fetal organs tends to remain constant, despite a decrease in arterial $\mathrm{O}_{2}$ content (2-4). There are, however, important differences between organs as to how this stability of oxygen consumption is achieved and to the level of arterial $\mathrm{O}_{2}$ content below which $\mathrm{O}_{2}$ uptake is drastically reduced. In the fetal circulatory response to acute

Received January 22, 1990; accepted April 11, 1990

Correspondence: Randall B. Wilkening, M.D., Associate Professor, c/o Diane Frelund, Division of Perinatal Medicine, B-199, University of Colorado Health Sciences Center, 4200 East Ninth Avenue, Denver, CO 80262.

Reprint requests: Randall B. Wilkening, M.D. Division of Perinatal Medicine, Box B-199, University of Colorado Health Sciences Center, 4200 East Ninth Avenue, Denver, CO 80262.

Supported by NIH Program Grant HD-00781 and Project Grant HD-01866. D.W.B. was supported by NIH Training Grant HD-07186. hypoxia, cardiac output is redistributed, favoring CNS and heart at the expense of other regions (5-8). The increase in cerebral and coronary blood flow allows the fetal brain and heart to maintain a high rate of oxygen consumption without increasing oxygen extraction (i.e. the arterial minus venous $\mathrm{O}_{2}$ content difference expressed as percent of arterial $\mathrm{O}_{2}$ content), and in the presence of an arterial $\mathrm{O}_{2}$ content that, for the brain, can be as low as the $1 \mathrm{mM}$ level $(2,4)$. By contrast, the gut maintains oxygen consumption by increasing oxygen extraction while blood flow is decreasing, and can do so only if arterial $\mathrm{O}_{2}$ content does not decrease below $2 \mathrm{mM}$ (3). Furthermore, observations on fetal hepatic blood flow and $\mathrm{O}_{2}$ uptake seem to indicate that the uptake decreases in linear relation to the amount of oxygen delivered via the hepatic circulation (9), suggesting that there is no range of fetal oxygenation over which fetal hepatic oxygen consumption is stable.

The fetal hind limb is of particular interest in this regard because it is representative of carcass (i.e. nonvisceral) fetal tissues, the whole of which in the mature fetal lamb receives about $35 \%$ of cardiac output under normal conditions (10). Carcass tissues have been implicated as important sites of vasomotor reactivity during hypoxic stress $(6,11)$.

Our study was designed to determine by within-animal comparison whether the fetal hind limb maintains oxygen consumption as fetal oxygenation decreases and, if so, over what range of oxygenation this is accomplished and how this stability of oxygen consumption is achieved. Changes in fetal arterial oxygenation were produced by incremental occlusion of uterine blood flow (12). Note that this procedure causes an increase in fetal $\mathrm{PCO}_{2}$ along with a decrease in fetal oxygenation (12), so that the induced changes could be considered graded fetal asphyxia. Blood flow to the hind limb tissues were measured continuously through the external iliac artery by means of transit-time methodology and oxygen uptake was determined by application of the Fick principle (13).

\section{MATERIALS AND METHODS}

Surgery and animal care. Six mixed-breed (Columbia-Rambouillet) ewes with time-dated pregnancies were fasted for $48 \mathrm{~h}$ before surgery at 118 to $125 \mathrm{~d}$ gestation (term is $150 \mathrm{~d}$ ). Under i.v. pentobarbital sedation and $1 \%$ tetracaine hydrochloride spinal anesthesia (10-12 mg), the uterus was delivered through a midline infraumbilical incision. A 12-mm cuff-type balloon occluder (In Vivo Metric Systems, Healdsburg, CA) was positioned around the maternal terminal aorta below the external iliac arteries. This arterial segment, known also as the common internal iliac artery, gives rise to the arteries which are the main source of blood supply to the pregnant sheep uterus. Polyvinyl catheters ( $1.38 \mathrm{~mm}$ outer diameter) were placed in a fetal brachial vein for systemic infusion and in a fetal pedal artery with the tip positioned in the external iliac artery for blood sampling and arterial blood pressure monitoring. The hind limb containing 
this arterial catheter was designated the nonstudy limb. A smaller polyvinyl catheter ( $1.00 \mathrm{~mm}$ outer diameter) was inserted in the contralateral pudendoepigastric venous trunk with the tip advanced $1 \mathrm{~cm}$ into the external iliac vein. The hind limb drained by this iliac vein was designated the study limb. These catheterization procedures were designed to minimize interference with the circulation of the study limb and to avoid changes in the position of the tip of the venous sampling catheter during fetal movements $(13,14)$. The deep circumflex iliac artery and vein and the pudendoepigastric arterial and venous trunks were ligated on the study limb side. The purpose of these ligations was to produce a circulation in which the external iliac artery and vein carry hind limb blood flow only (13). A catheter was also placed in the amniotic fluid cavity for fetal blood pressure reference and instillation of antibiotic. Pancuronium bromide (Organon Inc., West Orange, $\mathrm{NJ}$ ) was injected during surgery via the brachial vein catheter $(0.2 \mathrm{mg} / \mathrm{kg}$ estimated fetal wt $)$ to produce muscle relaxation.

A 3-mm transit time ultrasonic blood flow transducer (Transonic Systems, Inc., Ithaca, NY) (13) was positioned around the external iliac artery of the study limb for continuous blood flow measurement. The transducers were precalibrated in vitro for linearity of response from 0 to $150 \mathrm{~mL} / \mathrm{min}$; zero flow corrections were obtained in situ at autopsy. All catheters and the flow transducer cable were led s.c. to an external flank pouch.

The animals recovered promptly from surgery and were standing and feeding in their individual pens within $6 \mathrm{~h}$. Antibiotic was administered and catheters maintained as previously described (13). The ewes were given water and fed ad libitum with their standard alfalfa pellet diet.

Study design. The animals were allowed $7 \mathrm{~d}$ of recovery from operative stress before study. No experiments were performed during this recovery period. Before the initiation of our study, the animals underwent a 2-h study on the effect of pancuronium on pelvic limb blood flow and oxygen consumption (13). The animals were allowed a minimum of $24 \mathrm{~h}$ to recover from this experiment before proceeding with our study. The animals were studied on one to three separate occasions between 127 and 141 $\mathrm{d}$ of gestation (mean $135 \mathrm{~d}$ ). Animals were allowed a minimum of $24 \mathrm{~h}$ to recover between experiments. On each study day, a normal control period was established over 45 min during which four to six sets of blood samples for $\mathrm{Hb}$ concentration and oxygen saturation $(0.5 \mathrm{~mL}$ into heparin-coated capillaries) were drawn simultaneously from the external iliac artery and vein catheters. Mean arterial blood pressure and heart rate were recorded and blood flow was measured continuously during each sample set. Sample sets required 2 min to draw; blood flow for the sample set was determined as the average of the mean blood flow noted every 0.2 min during the sampling interval.

Fetal hypoxia was then produced by partial occlusion of the maternal common internal iliac artery. Decreasing levels of fetal arterial oxygenation were produced by progressively reducing oxygen delivery to the uterus through incremental occlusion of uterine blood flow. After approximately $15 \mathrm{~min}$ at each new level of oxygenation, the four to six sample sets for $\mathrm{Hb}$ concentration and oxygen saturation and the blood pressure, heart rate, and blood flow measurements were repeated. On each study day, three progressively increasing levels of fetal hypoxia were examined (on one occasion each, two, four, or five levels of hypoxia were examined). The most severe degree of hypoxia was chosen to produce a fetal arterial oxygen saturation less than $25 \%$. At the end of the experiment, the animals were killed by injection of a euthanasia solution. The condition and placement of the catheters and blood flow transducer were verified, and the fetal and hind limb tissue wt were measured.

Measurements and calculations.Amniotic pressure and fetal arterial blood pressure were measured with a strain gauge transducer (Gould-Statham, Cleveland, OH). Fetal arterial blood pressure was corrected for intraamniotic pressure. Fetal heart rate was counted from the arterial pulse frequency. Hind limb blood flow was measured as described above and expressed per $100 \mathrm{~g}$. Vascular resistance $\left(\mathrm{mm} \mathrm{Hg} \cdot \mathrm{mL}^{-1} \cdot \mathrm{min} \cdot 100 \mathrm{~g}\right)$ in the hind limb was calculated as:

\section{CVR}

$$
=\frac{\text { mean arterial blood pressure }- \text { central venous pressure }}{\text { hind limb blood flow }}
$$

where CVR is calculated vascular resistance; central venous pressure was assumed to be $3 \mathrm{~mm} \mathrm{Hg}$.

Blood $\mathrm{Hb}$ concentration expressed as oxygen capacity $\left(\left[\mathrm{O}_{2} \mathrm{CAP}\right] ; \mathrm{mm} / \mathrm{L}\right)$ and oxyhemoglobin saturation $\left(\mathrm{SO}_{2}, \%\right)$ were measured in duplicate by an automatic direct reading spectrophotometer (OSM-2, Radiometer, Copenhagen, Denmark). Blood oxygen content $\left(\left[\mathrm{O}_{2}\right] ; \mathrm{mm} / \mathrm{L}\right)$ was calculated as:

$$
\left[\mathrm{O}_{2}\right]=\left[\mathrm{O}_{2} \mathrm{CAP}\right] \times \mathrm{SO}_{2} / 100
$$

The contribution of physically dissolved oxygen to total oxygen content in fetal blood was considered negligible. The spectrophotometer $\mathrm{O}_{2}$ capacity measurement was calibrated with blood samples of known $\mathrm{Hb}$ content. $\mathrm{Hb}$ was analyzed in triplicate after conversion to cyanmethemoglobin in a DU7 spectrophotometer (Beckman Instruments, Inc., Fullerton, CA) using a 10$\mathrm{mm}$ cuvette at wavelength $540 \mathrm{~nm} . \mathrm{O}_{2}$ capacity was calculated as 22.8 times the absorbance.

Oxygen consumption by the hind limb $\left(\mathrm{V}_{2} ; \mu \mathrm{m} \cdot \mathrm{min}^{-1} \cdot 100\right.$ $\mathrm{g}^{-1}$ ) was calculated by application of the Fick principle:

$$
\left.\mathrm{VO}_{2}=\mathrm{F} \times\left(\left[\mathrm{O}_{2}\right]_{\mathrm{a}}-\mathrm{O}_{2}\right]_{\mathrm{v}}\right)
$$

where $\mathrm{F}\left(\mathrm{mL} \cdot \mathrm{min}^{-1} \cdot 100 \mathrm{~g}^{-1}\right)$ is the mean blood flow determined during each sampling interval as outlined above, $\left[\mathrm{O}_{2}\right]_{\mathrm{a}}$ is the oxygen content in the external iliac artery, and $\left[\mathrm{O}_{2}\right]_{\mathrm{v}}$ is the oxygen content in the external iliac vein of the study limb, both expressed as $\mu \mathrm{m} \cdot \mathrm{mL}^{-1}$. Oxygen delivery to the hind limb $\left(\mathrm{DO}_{2} ; \mu \mathrm{m} \cdot \mathrm{min}^{-1}\right)$ was calculated as the product of hind limb blood flow times the oxygen content in the external iliac artery. Hind limb oxygen extraction coefficient (\%) was calculated as:

$$
\mathrm{O}_{2} \text { extraction }=\left(\left[\mathrm{O}_{2}\right]_{\mathrm{a}}-\left[\mathrm{O}_{2}\right]_{\mathrm{v}}\right) /\left[\mathrm{O}_{2}\right]_{\mathrm{a}} \times 100
$$

Data analysis. The mean of each variable was determined for each study during the control period and at each level of fetal oxygenation. Where appropriate, means and SEM were determined across studies. Statistical analysis of heart rate, blood pressure, blood flow, calculated vascular resistance, and oxygen consumption was done using repeated measures analysis of variance (15) with the SAS statistical software package (16). For hind limb oxygen delivery, blood flow, and oxygen consumption, nonlinear least squares regressions of each variable versus fetal arterial oxygen content were used to obtain individual parameter estimates for each animal on each study day.

To analyze the relation of hind limb oxygen delivery $\left(\mathrm{DO}_{2}\right)$ to arterial oxygen content $\left(\left[\mathrm{O}_{2}\right]_{\mathrm{a}}\right)$, we used the empirical equation of Peeters et al. (5):

$$
\mathrm{DO}_{2}=\mathrm{A}_{1}+\mathrm{B}_{1} \times \ln \left[\mathrm{O}_{2}\right]_{\mathrm{a}}
$$

where $A_{1}$ and $B_{1}$ are the parameters to be estimated. By substitution, the equation relating hind limb blood flow $(\mathrm{F})$ to arterial oxygen content is:

$$
\mathrm{F}=\left(\mathrm{A}_{1}+\mathrm{B}_{1} \times \ln \left[\mathrm{O}_{2}\right]_{\mathrm{a}}\right) /\left[\mathrm{O}_{2}\right]_{\mathrm{a}}
$$

For the relationship of hind limb oxygen consumption $\left(\mathrm{V}_{2}\right)$ versus $\left[\mathrm{O}_{2}\right]_{\mathrm{a}}$, we assumed that as $\left[\mathrm{O}_{2}\right]_{\mathrm{a}}$ increases, $\dot{\mathrm{VO}} \mathrm{O}_{2}$ increases asymptotically to a maximum at high values of $\left[\mathrm{O}_{2}\right]_{\mathrm{a}}$ :

$$
\dot{\mathrm{V}} \mathrm{O}_{2}=\dot{\mathrm{V}} \mathrm{O}_{2} \max \left\{1-\exp \left(\mathrm{A}_{2}-\mathrm{B}_{2} \times\left[\mathrm{O}_{2}\right]_{\mathrm{a}}\right)\right\}
$$

The parameters obtained for each animal on each study day were averaged to obtain an overall mean equation for each 
variable $\left(\mathrm{DO}_{2}, \mathrm{~F}\right.$, or $\left.\dot{\mathrm{V}} \mathrm{O}_{2}\right)$. The residual variance was computed as the weighted average of the individual residual variances. The parameter estimates were subjected to analyses of variance to obtain maximum likelihood estimates for the other two components of variance, i.e. between animals and between days within animals. The medians of each parameter were determined across study days to construct median curves that appear to be more representative than the corresponding mean curves. $p$ values $<0.05$ indicated statistically significant differences.

\section{RESULTS}

A total of 12 studies was performed on the six animals. One animal (no. 2) was studied on three separate occasions; one animal (no. 6) was studied once. All other animals were studied on two separate days. Studies occurred 8 to $16 \mathrm{~d}$ postoperatively $(12 \pm 1 \mathrm{~d}$, mean \pm SEM). Table 1 presents the fetal age, wt, and study limb wt at autopsy for each animal. Because the day of autopsy occurred an average of $3 \mathrm{~d}$ after the day of study, Table 1 also presents an estimate of the individual study limb wt as of the day of study calculated by means of a fetal growth curve that was constructed for sheep of the same breed (1). The estimated wt of the study limb at day of study was used for comparison with data in the literature.

Table 2 shows the mean values for fetal arterial oxygen content, arterial oxygen saturation, heart rate, mean arterial blood pressure, study limb blood flow, calculated vascular resistance, oxygen delivery and oxygen consumption per $100 \mathrm{~g}$, and study limb oxygen extraction for each animal on each study day at the various levels of oxygenation. Fetal arterial oxygen content was varied from 4.93 to $0.69 \mathrm{mM}$ and arterial oxygen saturation from 58.7 to $9.7 \%$. Because the cardiovascular and metabolic responses to hypoxia were markedly dependent on the degree of hypoxia, the data in Table 2 were grouped into three ranges of $\left.\left[\mathrm{O}_{2}\right]_{\mathrm{a}}: a\right)$ control $\left(\left[\mathrm{O}_{2}\right]_{\mathrm{a}}>2.7 \mathrm{mM}, 3.26 \pm 0.19 \mathrm{mM}\right.$, mean \pm $\mathrm{SE}) ; b)$ moderate hypoxia $\left(\left[\mathrm{O}_{2}\right]_{\mathrm{a}} \leq 2.7,>1.5 \mathrm{mM}, 2.13 \pm 0.07\right.$ $\mathrm{mM})$; and $c$ ) severe hypoxia $\left(\left[\mathrm{O}_{2}\right]_{\mathrm{a}} \leq 1.5 \mathrm{mM}, 1.18 \pm 0.07 \mathrm{mM}\right)$ for statistical analysis. One animal (no. 6) was excluded from this analysis because there were no data at moderate hypoxia; also excluded were hypoxic values corresponding to fetal arterial oxygen contents greater than $2.7 \mathrm{mM}$. The remaining values were averaged within each range for each animal, leaving 33 observations on 11 study days for analysis in Table 3 .

In comparison to control, heart rate increased significantly during moderate hypoxia $(169 \pm 7$ versus $194 \pm 6$ beats $/$ min, $p$ $<0.01)$ and then decreased during severe hypoxia $(148 \pm 8$ beats $/ \mathrm{min}, p<0.01)$. Blood pressure did not change significantly during moderate hypoxia $(47 \pm 1$ versus $48 \pm 1 \mathrm{~mm} \mathrm{Hg}, p>$ $0.1)$, but increased in severe hypoxia $(55 \pm 2 \mathrm{~mm} \mathrm{Hg}, p<0.001)$. Hind limb blood flow increased significantly in moderate hypoxia $\left(19.9 \pm 1.0\right.$ versus $22.2 \pm 1.4 \mathrm{~mL} \cdot \mathrm{min}^{-1} \cdot 100 \mathrm{~g}^{-1}, p<$ $0.01)$ and decreased in severe hypoxia $\left(8.9 \pm 1.8 \mathrm{~mL} \cdot \mathrm{min}^{-1} \cdot 100\right.$ $\left.\mathrm{g}^{-1}, p<0.001\right)$. The calculated vascular resistance across the hind limb decreased in moderate hypoxia $(2.25 \pm 0.11$ versus $\left.2.10 \pm 0.14 \mathrm{~mm} \mathrm{Hg} \cdot \mathrm{mL}^{-1} \cdot \mathrm{min} \cdot 100 \mathrm{~g}, p<0.05\right)$ and increased in severe hypoxia $\left(11.26 \pm 3.60 \mathrm{~mm} \mathrm{Hg} \cdot \mathrm{mL}^{-1} \cdot \mathrm{min} \cdot 100 \mathrm{~g}, p<\right.$ $0.05)$. Hind limb oxygen consumption decreased during moderate hypoxia $\left(16.71 \pm 0.79\right.$ versus $14.74 \pm 1.16 \mu \mathrm{m} \cdot \mathrm{min}^{-1} \cdot 100$ $\left.\mathrm{g}^{-1}, p<0.05\right)$ and then decreased markedly in severe hypoxia $\left(4.69 \pm 1.22 \mu \mathrm{m} \cdot \mathrm{min}^{-1} \cdot 100 \mathrm{~g}^{-1}, p<0.001\right)$.

Figure 1 illustrates the curvilinear relationships of hind limb blood flow, oxygen consumption, and oxygen delivery to fetal arterial oxygen content. Panels $A, C$, and $E$ show the population median curve derived from the individual study day curves through a scatter of the original data points for study limb oxygen delivery, blood flow, and oxygen consumption. Panels $B, D$, and $F$ show the median curve and the predicted curves for each animal on each study day for these same variables.

The relationship between hind limb oxygen delivery and arterial oxygen content is illustrated in Panels $I A$ and $I B$. Based on equation 5 , the median curve describing this relationship is:

$$
\mathrm{DO}_{2}=7.01+48.52 \times \ln \left[\mathrm{O}_{2}\right]_{\mathrm{a}}
$$

Analysis of the three components of variability for oxygen delivery (between animals, between days within animals, and between measures within days-residual variation) showed that betweenanimal variability was small and increased with increasing $\left[\mathrm{O}_{2}\right]_{\mathrm{a}}$. Residual variation accounted for between 15 and $26 \%$ of the total variability. The greatest component of variation was between days within animals, accounting for $68-74 \%$ of the total variability, decreasing with increasing $\left[\mathrm{O}_{2}\right]_{\mathrm{a}}$.

Panels $I C$ and $I D$ show the relationship between hind limb blood flow and arterial oxygen content. Analysis of the data using equation 6 yields the overall median equation:

$$
\mathrm{F}=\left(7.8+52.0 \times 1 \mathrm{n}\left[\mathrm{O}_{2}\right]_{\mathrm{a}}\right) /\left[\mathrm{O}_{2}\right]_{\mathrm{a}}
$$

Blood flow increases inversely with $\left[\mathrm{O}_{2}\right]_{\mathrm{a}}$, achieving a maximum

Table 1. Individual animal age, wt, and study limb wt at autopsy and estimated study limb wt on day of study

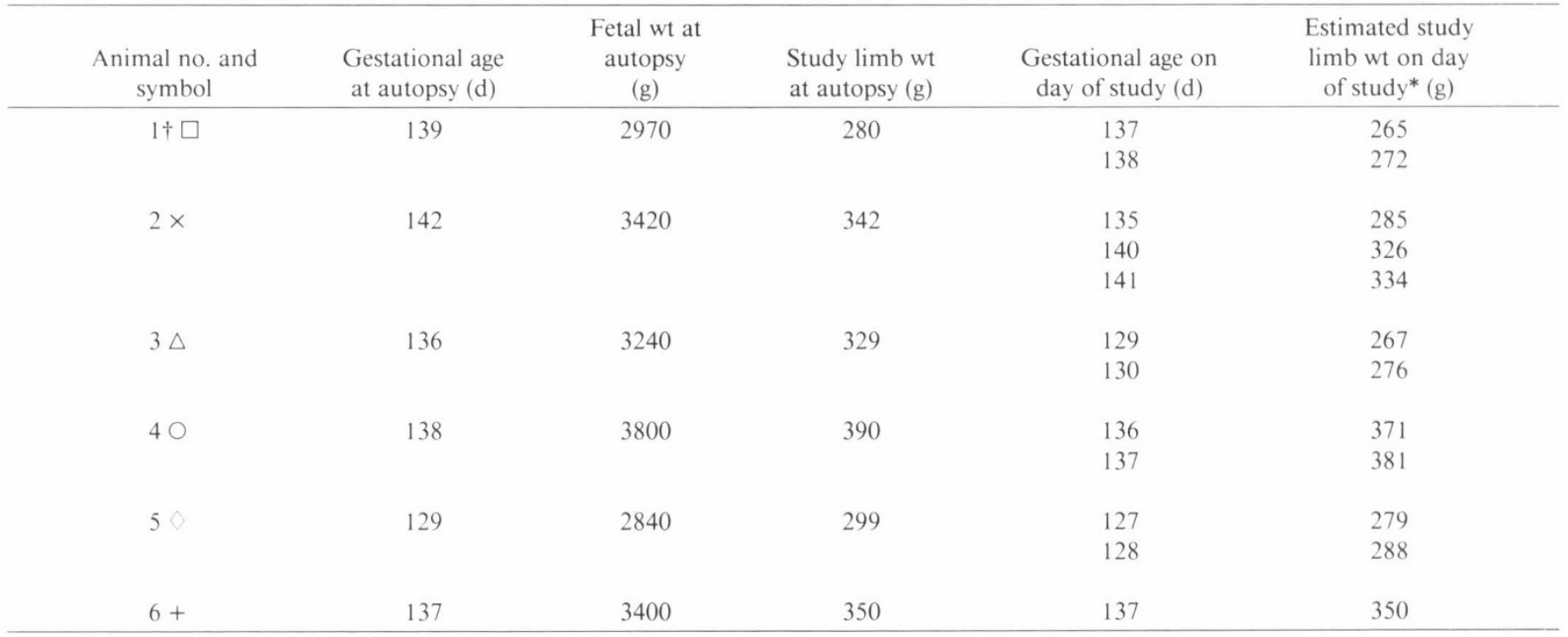

* Study limb wt on the day of study for each individual animal was estimated as the product of the estimated fetal wt ( 1 ) on day of study times the limb wt to fetal wt ratio determined at autopsy for each individual animal.

+ Animal 1 was a twin gestation in which only one fetus was studied. 
Table 2. Individual animal mean oxygen, cardiovascular, and metabolic data*

\begin{tabular}{|c|c|c|c|c|c|c|c|c|c|c|}
\hline Animal no. & $\begin{array}{c}\text { Gestational age } \\
\text { on day of } \\
\text { experiment }\end{array}$ & {$\left[\mathrm{O}_{2}\right]_{\mathrm{a}}$} & $\mathrm{SaO}_{2}$ & HR & $\mathrm{BP}$ & $\mathrm{F}$ & CVR & $\mathrm{DO}_{2}$ & $\dot{\mathrm{v}} \mathrm{O}_{2}$ & $\mathrm{O}_{2}$ ext \\
\hline \multirow[t]{4}{*}{1} & $137 \dagger$ & 2.93 & 50.6 & 168 & 44 & 21.7 & 1.89 & 63.7 & 20.2 & 31.7 \\
\hline & & 2.31 & 40.0 & 197 & 42 & 26.3 & 1.48 & 60.9 & 23.6 & 39.4 \\
\hline & & 2.00 & 34.1 & 200 & 42 & 27.8 & 1.40 & 55.6 & 16.2 & 29.0 \\
\hline & & 1.47 & 23.5 & 163 & 44 & 14.4 & 2.85 & 21.3 & 11.1 & 52.4 \\
\hline \multirow[t]{6}{*}{1} & 138 & 2.87 & 51.8 & 182 & 45 & 21.0 & 2.00 & 60.1 & 16.7 & 28.6 \\
\hline & & 2.39 & 41.9 & 175 & 45 & 23.0 & 1.83 & 54.6 & 15.6 & 28.5 \\
\hline & & 1.91 & 33.2 & 203 & 46 & 26.1 & 1.65 & 49.8 & 15.6 & 31.4 \\
\hline & & 1.49 & 26.0 & 218 & 45 & 24.6 & 1.71 & 36.8 & 13.5 & 36.9 \\
\hline & & 1.20 & 20.7 & 166 & 47 & 19.3 & 2.28 & 22.8 & 10.6 & 47.5 \\
\hline & & 1.05 & 18.2 & 139 & 55 & 8.6 & 6.05 & 9.0 & 4.8 & 53.3 \\
\hline \multirow[t]{4}{*}{2} & 135 & 2.96 & 45.5 & 159 & 48 & 29.2 & 1.54 & 86.4 & 20.0 & 23.0 \\
\hline & & 2.55 & 38.6 & 172 & 49 & 29.8 & 1.54 & 75.6 & 19.8 & 26.3 \\
\hline & & 1.84 & 27.5 & 189 & 48 & 36.2 & 1.24 & 66.2 & 23.3 & 35.3 \\
\hline & & 1.24 & 18.0 & 133 & 52 & 18.4 & 2.66 & 22.9 & 11.0 & 48.4 \\
\hline \multirow[t]{4}{*}{2} & 140 & 2.88 & 43.0 & 130 & 50 & 18.3 & 2.57 & 52.6 & 12.6 & 24.0 \\
\hline & & 2.54 & 37.8 & 155 & 51 & 18.8 & 2.55 & 47.8 & 13.5 & 28.3 \\
\hline & & 1.69 & 24.4 & 184 & 52 & 19.8 & 2.47 & 33.4 & 12.8 & 38.5 \\
\hline & & 1.40 & 19.4 & 115 & 57 & 7.5 & 7.20 & 10.5 & 4.2 & 40.7 \\
\hline \multirow[t]{3}{*}{2} & 141 & 2.73 & 41.9 & 144 & 51 & 18.3 & 2.62 & 50.1 & 14.2 & 28.6 \\
\hline & & 1.91 & 28.0 & 171 & 52 & 18.5 & 2.65 & 35.2 & 13.8 & 39.3 \\
\hline & & 1.50 & 21.1 & 94 & 63 & 2.7 & 22.22 & 4.1 & 2.3 & 55.3 \\
\hline \multirow[t]{4}{*}{3} & 129 & 4.93 & 58.7 & 182 & 45 & 15.9 & 2.64 & 78.1 & 19.8 & 25.6 \\
\hline & & 3.99 & 48.4 & 173 & 46 & 18.8 & 2.29 & 74.8 & 14.9 & 20.1 \\
\hline & & 2.33 & 28.1 & 177 & 49 & 17.6 & 2.61 & 33.3 & 10.0 & 30.0 \\
\hline & & 1.19 & 13.8 & 137 & 56 & 5.4 & 9.81 & 6.5 & 2.5 & 37.8 \\
\hline \multirow[t]{5}{*}{3} & 130 & 3.45 & 47.4 & 218 & 48 & 18.6 & 2.42 & 64.0 & 15.1 & 23.8 \\
\hline & & 3.11 & 43.1 & 219 & 46 & 20.7 & 2.08 & 64.4 & 16.6 & 26.0 \\
\hline & & 2.56 & 36.1 & 201 & 47 & 23.8 & 1.85 & 50.9 & 11.8 & 23.4 \\
\hline & & 1.45 & 20.0 & 169 & 55 & 15.4 & 3.38 & 22.4 & 7.7 & 34.5 \\
\hline & & 0.96 & 12.7 & 150 & 56 & 6.9 & 7.68 & 6.6 & 2.2 & 33.3 \\
\hline \multirow[t]{4}{*}{4} & 136 & 3.39 & 51.0 & 161 & 50 & 18.6 & 2.53 & 62.8 & 17.9 & 28.6 \\
\hline & & 2.86 & 43.5 & 172 & 48 & 17.8 & 2.53 & 48.5 & 18.8 & 38.5 \\
\hline & & 1.84 & 27.6 & 241 & 52 & 19.7 & 2.49 & 36.2 & 17.8 & 49.5 \\
\hline & & 1.15 & 16.4 & 177 & 62 & 6.9 & 8.55 & 7.9 & 3.7 & 46.1 \\
\hline \multirow[t]{4}{*}{4} & 137 & 2.85 & 46.3 & 155 & 49 & 19.3 & 2.38 & 53.3 & 17.7 & 33.0 \\
\hline & & 2.32 & 36.2 & 211 & 49 & 18.2 & 2.53 & 41.2 & 15.4 & 37.9 \\
\hline & & 1.67 & 26.1 & 180 & 48 & 21.2 & 2.12 & 34.7 & 15.5 & 44.9 \\
\hline & & 0.69 & 9.7 & 140 & 63 & 1.4 & 42.86 & 1.0 & 0.2 & 15.9 \\
\hline \multirow[t]{4}{*}{5} & 127 & 3.39 & 50.2 & 185 & 43 & 19.9 & 2.01 & 67.1 & 14.3 & 21.2 \\
\hline & & 2.69 & 39.2 & 193 & 44 & 21.6 & 1.90 & 54.1 & 14.2 & 26.4 \\
\hline & & 2.06 & 29.6 & 206 & 45 & 20.5 & 2.05 & 39.4 & 13.3 & 33.5 \\
\hline & & 0.91 & 11.7 & 181 & 52 & 3.6 & 13.61 & 3.3 & 0.8 & 24.2 \\
\hline \multirow[t]{4}{*}{5} & 128 & 3.45 & 53.0 & 174 & 42 & 18.5 & 2.11 & 63.9 & 15.2 & 24.1 \\
\hline & & 2.72 & 41.4 & 214 & 42 & 19.3 & 2.02 & 50.3 & 11.4 & 23.2 \\
\hline & & 1.81 & 26.9 & 213 & 45 & 19.7 & 2.13 & 35.5 & 9.3 & 26.0 \\
\hline & & 1.02 & 13.9 & 159 & 50 & 9.0 & 5.22 & 9.1 & 1.4 & 15.7 \\
\hline \multirow[t]{4}{*}{6} & 137 & 3.17 & 49.9 & 164 & 54 & 19.8 & 2.58 & 62.0 & 21.8 & 35.3 \\
\hline & & 2.88 & 44.7 & 164 & 52 & 22.6 & 2.17 & 64.9 & 21.9 & 33.9 \\
\hline & & 1.46 & 22.0 & 163 & 58 & 21.1 & 2.61 & 30.8 & 14.0 & 45.9 \\
\hline & & 0.82 & 11.6 & 151 & 68 & 2.5 & 26.00 & 2.1 & 0.4 & 14.1 \\
\hline Mean \pm SEM $\ddagger$ & & $3.25 \pm 0.17$ & $49.1 \pm 1.3$ & $168 \pm 6$ & $47 \pm 1$ & $19.9 \pm 0.9$ & $2.27 \pm 0.10$ & $63.7 \pm 3.0$ & $17.1 \pm 0.8$ & $27.3 \pm 1.3$ \\
\hline
\end{tabular}

* Note: Age is in days, $\left[\mathrm{O}_{2}\right]_{\mathrm{a}}$ is fetal arterial oxygen content in $\mathrm{mM}, \mathrm{SaO}_{2}$ is fetal arterial oxygen saturation in \%, HR is fetal heart rate in beats/

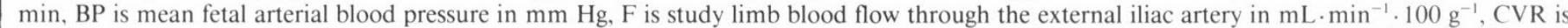
study limb calculated vascular resistance in $\mathrm{mm} \mathrm{Hg} \cdot \mathrm{mL}^{-1} \cdot \mathrm{min} \cdot 100 \mathrm{~g}, \mathrm{DO}_{2}$ is study limb oxygen delivery in $\mu \mathrm{m} \cdot \mathrm{min}^{-1} \cdot 100 \mathrm{~g}{ }^{-1}, \dot{\mathrm{VO}} 2$ is study limb oxygen consumption in $\mu \mathrm{m} \cdot \mathrm{min}^{-1} \cdot 100 \mathrm{~g}^{-1}$, and $\mathrm{O}_{2}$ ext is study limb oxygen extraction in $\%$.

$\dagger$ The first values given for each day of study for each animal represent control values.

$\ddagger$ Mean \pm SEM for control values. 
Table 3. Descriptive statistics and repeated measures analysis of variance for heart rate, blood pressure, blood flow, vascular resistance, and oxygen consumption during control, moderate hypoxia, and severa hypoxia*

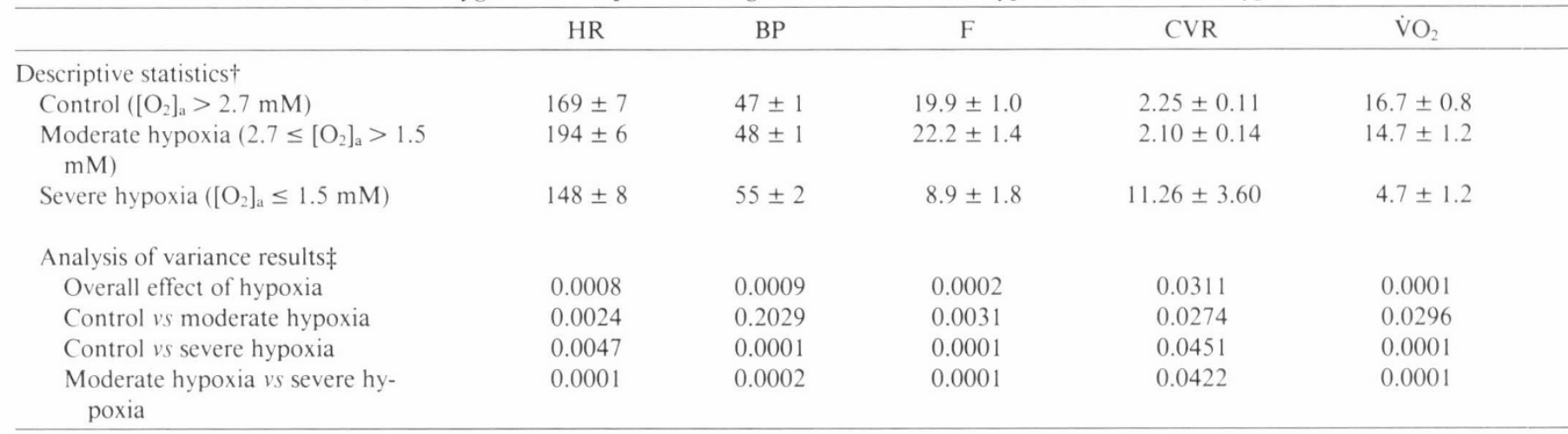

* Note: HR is fetal heart rate in beats/min, BP is mean fetal arterial blood pressure in $\mathrm{mm} \mathrm{Hg}, \mathrm{F}$ is study limb blood flow through the external iliac artery in $\mathrm{mL} \cdot \mathrm{min}^{-1} \cdot 100 \mathrm{~g}^{-1}$, CVR is study limb calculated vascular resistance in $\mathrm{mm} \mathrm{Hg} \cdot \mathrm{mL}^{-1} \cdot \mathrm{min} \cdot 100 \mathrm{~g}$, and $\dot{\mathrm{VO}} 2$ is study limb oxygen consumption in $\mu \mathrm{m} \cdot \mathrm{min}^{-1} \cdot 100 \mathrm{~g}^{-1}$.

$\dagger$ Mean \pm SEM based on 11 studies.

$\ddagger p$ values.
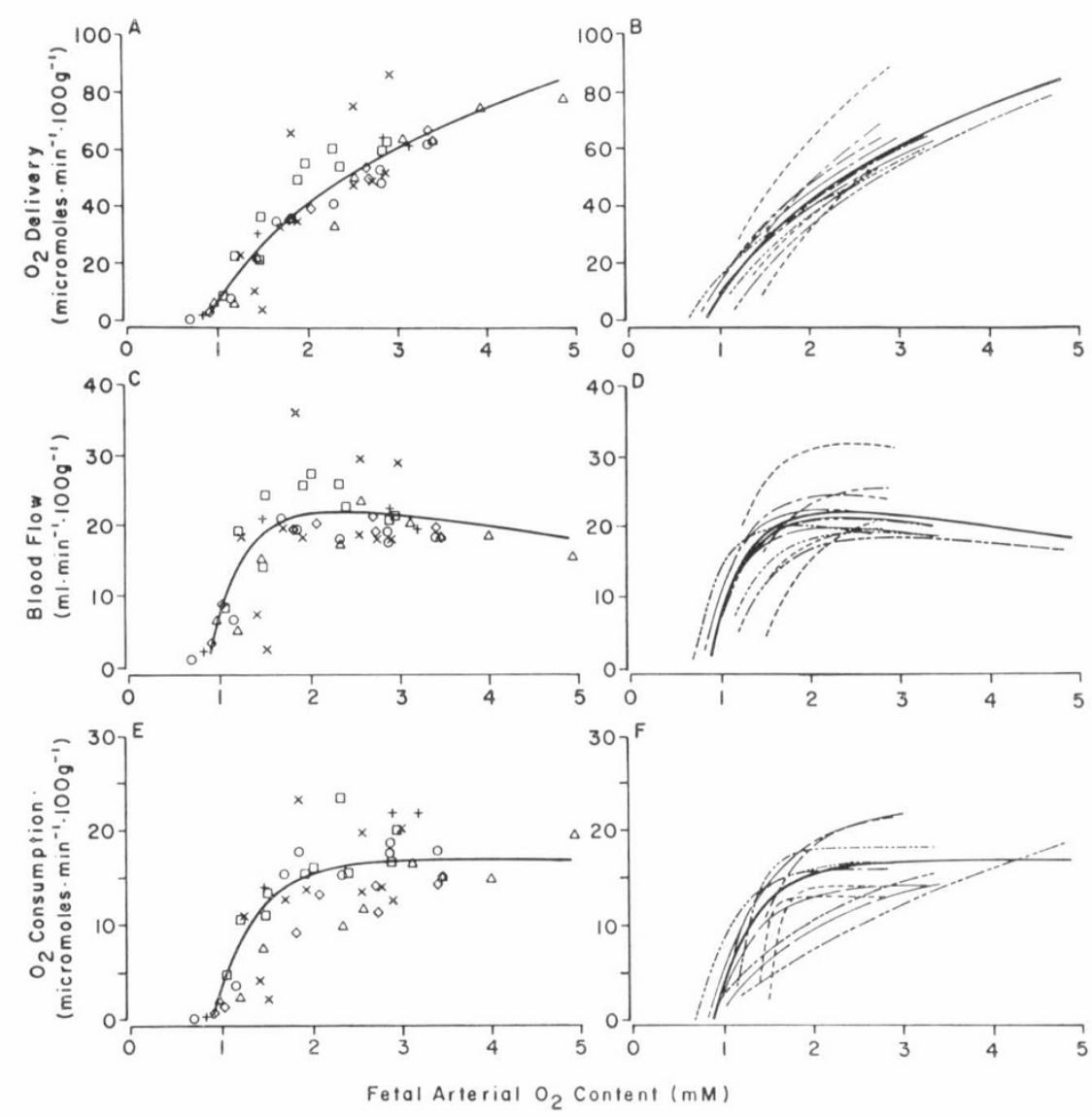

Fig. 1. Comparison of the population median curve relationship to fetal arterial oxygen content (solid line) with the individual study curve relationships to fetal arterial oxygen content (dashed line) for hind limb oxygen delivery (panel $A$ vs $B$ ), hind limb blood flow (panel $C$ vs $D$ ), and hind limb oxygen consumption ( panel $E v s F$ ). See Table 1 for symbol explanation.

between 2.7 and $2.0 \mathrm{mM}$. Blood flow then decreases abruptly between 2.0 and $1.5 \mathrm{mM}$. Analysis of the three components of variation of hind limb blood flow revealed the greatest component of variation to be between days within animals. This component of variance accounted for 38 to $93 \%$ of the total variability, decreasing as $\left[\mathrm{O}_{2}\right]_{\mathrm{a}}$ increased. The variability between animals was small but increased with increasing $\left[\mathrm{O}_{2}\right]_{\mathrm{a}}$. The residual variance comprised 7 to $45 \%$ of the total variability over the range of arterial oxygen contents studied.

The relationship between hind limb oxygen consumption and arterial oxygen content is shown in Panels $I E$ and $I F$. Each study day was subjected to analysis by submitting the three parameter model given by equation 7 to a nonlinear least squares regression as previously described. Using this approach, one study day (animal no. 2 at 135 d gestation) was excluded because the four observations on that day did not cover an appropriate range to compute an exponential model. Thus, individual parameter estimates were determined for each animal on 11 study days resulting in the median equation:

$$
\dot{\mathrm{V}}_{2}=16.99 \times\left\{1-\exp \left(1.95-2.20 \times\left[\mathrm{O}_{2}\right]_{\mathrm{a}}\right)\right\}
$$

As noted previously, hind limb oxygen consumption remained 
relatively constant down to values of arterial oxygen contents between 2.0 and $1.5 \mathrm{mM}$. Below this level of arterial oxygen content, $\mathrm{VO}_{2}$ fell precipitously. Examination of the components of hind limb oxygen consumption variation showed that the residual variance accounted for much less of the total variability compared with blood flow and oxygen delivery, whereas between-animal variance was 35 to $97 \%$ of the total variability. Between-days within-animals variance comprised 3 to $43 \%$ of the total variability.

The function describing the relationship between hind limb oxygen extraction and arterial oxygen content was derived by a modification of the Fick principle:

$$
\mathrm{O}_{2} \text { extraction }=\dot{\mathrm{VO}_{2}} / \mathrm{DO}_{2}
$$

Substituting equations 8 and 10 into equation 11 yields the equation:

$\mathrm{O}_{2}$ extraction $=16.99 \times\{1-\exp (1.95-2.20$

$$
\left.\left.\times\left[\mathrm{O}_{2}\right]_{\mathrm{a}}\right)\right\} /\left(7.01+48.52 \times \ln \left[\mathrm{O}_{2}\right]_{\mathrm{a}}\right)
$$

This curve is plotted through a scatter of the original data points in Figure 2. In this representation, oxygen extraction increases exponentially as an inverse function of arterial oxygen content from control values of $27.3 \pm 1.3 \%$ reaching a maximum of approximately $55 \%$ at approximately $1.1 \mathrm{mM}\left[\mathrm{O}_{2}\right]_{\mathrm{a}}$. Below this level of arterial oxygen content, oxygen extraction falls precipitously.

\section{DISCUSSION}

The results of our study demonstrate that the response of fetal hind limb $\mathrm{O}_{2}$ uptake to acute hypoxia depends on the level of arterial $\mathrm{O}_{2}$ content. As long as arterial $\mathrm{O}_{2}$ content does not decrease below a level of approximately 2 to $1.5 \mathrm{mM}$, fetal hind limb $\mathrm{O}_{2}$ uptake remains close to normal. Below the $1.5 \mathrm{mM}$ level, fetal hind limb $\mathrm{O}_{2}$ uptake decreases markedly and becomes virtually zero at an arterial $\mathrm{O}_{2}$ content of $0.9 \mathrm{mM}$. This response depends in part on the effect of graded hypoxia on hind limb blood flow. With a decrease of arterial $\mathrm{O}_{2}$ content from normal to $1.5 \mathrm{mM}$, fetal hind limb blood flow tends to increase, attains a maximum in the 2.7 to $2.0 \mathrm{mM}$ range and then returns to baseline value. These changes in hind limb flow are quite small, however, in comparison to the decrease in arterial oxygen. As a consequence, stability of $\mathrm{O}_{2}$ uptake above the $1.5 \mathrm{mM}$ limit is maintained primarily via an increase in $\mathrm{O}_{2}$ extraction, which rises from the control value of $27.3+1.3 \%$ to approximately $45 \%$. A further decrease in oxygenation triggers a marked decrease in hind limb blood flow, which reduces $\mathrm{O}_{2}$ delivery to virtually zero, as arterial $\mathrm{O}_{2}$ content approaches the $0.9 \mathrm{mM}$ level.

The pattern of hind limb blood flow response that we observed in this investigation is similar to the one described for the whole fetal carcass (5), despite differences in methodology. Although the carcass study used the microsphere technique for flow measurements and induced changes in fetal oxygenation by changing inspired maternal oxygen concentration, it also showed a small but statistically significant increase of blood flow during moderate hypoxia, followed by a sharp decline as $\mathrm{O}_{2}$ content decreased from 2 to $1 \mathrm{mM}$. This complex response is probably the result of different regulatory mechanisms, including local mechanisms of autoregulation and systemic mechanisms that regulate the distribution of cardiac output (5). Dawes et al. (11) were the first to demonstrate that the sharp decrease of blood flow to the fetal hind limb in severe hypoxia is mediated by reflexes from aortic chemoreceptor and by circulating catecholamines. Reuss et al. (17) studied the effect of $\alpha$-adrenergic blockade on the fetal circulatory response to severe hypoxia. The blockade did not eliminate completely the vasoconstriction in carcass tissue. Arginine vasopressin, which has been shown to be elevated in severely hypoxic fetal sheep (18) and to increase vascular resistance in the carcass both during exogenous infusion in normally oxygenated fetal sheep (19) and during hypoxia (20), may also contribute to the increased vascular tone in the hind limb during severe hypoxia. Much less is known about the response of the systemic mechanisms of fetal cardiovascular regulation to less severe hypoxia. In agreement with our study, one set of experiments on the effect of graded reductions in uterine blood flow on the fetal lamb showed no significant increase in fetal blood pressure and a tendency for fetal heart rate to increase in response to a small decrease in arterial $\mathrm{O}_{2}$ content (21). However, another study on the effect of reducing uterine blood flow showed fetal bradycardia and increased blood pressure at relatively high levels of oxygenation that did not significantly change fetal carcass blood flow (7). It is not clear what aspects of experimental design were responsible for these differences.

The results of our study imply that under normal physiologic

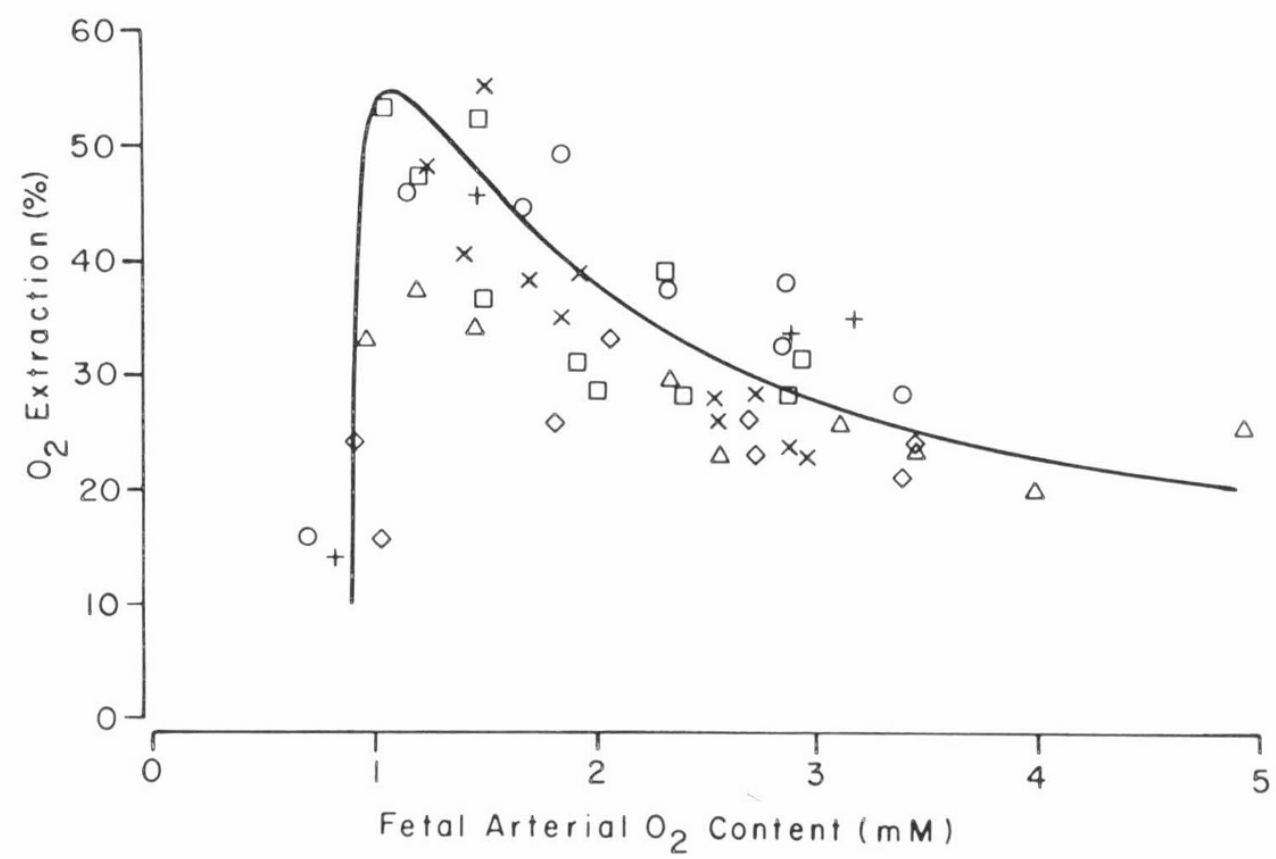

Fig. 2. Relationship of hind limb oxygen extraction to fetal arterial oxygen content (equation 10). See Table 1 for symbol explanation. 
conditions, the supply of $\mathrm{O}_{2}$ to the fetal hind limb exceeds by a significant margin the minimum that is required to sustain its oxidative metabolism, so that a reduction of $\mathrm{O}_{2}$ delivery to approximately $60 \%$ of normal (hind limb $\mathrm{O}_{2}$ delivery, 38 versus $63.7 \mu \mathrm{m} \cdot \mathrm{min}^{-1} \cdot 100 \mathrm{~g}^{-1}$ ) can be compensated for by an increase in $\mathrm{O}_{2}$ extraction. A similar safety margin of $\mathrm{O}_{2}$ supply was previously demonstrated for the fetal gut (3). In agreement with these data, the whole fetus responds to a graded reduction in uterine blood flow by maintaining a normal $\mathrm{O}_{2}$ consumption rate as long as umbilical supply does not decrease below approximately $55 \%$ of control (12). Therefore, measurements of $\mathrm{O}_{2}$ uptake by the whole fetus and by individual fetal organs define a state of moderate fetal hypoxia whose distinctive characteristic is the ability of the fetal organism to sustain a relatively high level of oxidative metabolism. The long-term effects of moderate fetal hypoxia are not clear. Note that Table 3 demonstrates a statistically significant $12 \%$ decrease of hind limb $\mathrm{O}_{2}$ consumption in association with moderate hypoxia. If this subtle metabolic effect were to persist under chronic hypoxia conditions, it could result in restriction of growth. The steep decline in hind limb blood flow and $\mathrm{O}_{2}$ uptake that begins at approximately 1.5 $\mathrm{mM}$ arterial $\mathrm{O}_{2}$ content represents an important mechanism for preserving $\mathrm{O}_{2}$ delivery to the fetal CNS and heart. Under acute hypoxia conditions, both cerebral and coronary blood flow tend to increase hyperbolically in inverse solution to arterial $\mathrm{O}_{2}$ content $(4,5,22)$. The blood flow shut down to organs such as the hind limb sustains this increase by allowing the heart to pump more blood into the cerebral and coronary circulations, at increased pressure and without increasing cardiac output. The decrease in $\mathrm{O}_{2}$ uptake reduces the decline in arterial $\mathrm{O}_{2}$ content by reducing the $\mathrm{O}_{2}$ demand by the whole fetus.

It is interesting to note that blood flow shut down to the fetal carcass and $\mathrm{O}_{2}$ supply to the vital organs are well coordinated. Hind limb blood flow becomes virtually zero at approximately $0.9 \mathrm{mM}\left[\mathrm{O}_{2}\right]_{\mathrm{a}}$ in the descending aorta. This corresponds to an $\mathrm{O}_{2}$ content in the ascending aorta of about $1.2 \mathrm{mM}(8)$, which is close to the lowest limit of oxygenation at which the fetus is able to maintain a normal rate of $\mathrm{O}_{2}$ delivery to the $\mathrm{CNS}$ and heart $(8,22)$.

\section{REFERENCES}

1. Battaglia FC, Meschia G 1986 An Introduction to Fetal Physiology. Academic Press, Orlando, FL, p 2

2. Jones Jr MD, Sheldon RE, Peeters LL, Meschia G, Battaglia FC, Makowski
EL 1977 Fetal cerebral oxygen consumption at different levels of oxygenation. J Appl Physiol 43:1080-1084

3. Edelstone DI, Holzman IR 1982 Fetal intestinal oxygen consumption at various levels of oxygenation. Am J Physiol 242:H50-H54

4. Fisher DJ, Heymann MA, Rudolph AM 1982 Fetal myocardial oxygen and carbohydrate consumption during acutely induced hypoxemia. Am J Physiol 242:H657-H661

5. Peeters LLH, Sheldon RE, Jones Jr MD, Makowski EL, Meschia G 1979 Blood flow to fetal organs as a function of arterial oxygen content. Am J Obstet Gynecol 135:637-646

6. Cohn HE, Sacks EJ, Heymann MA, Rudolph AM 1974 Cardiovascular responses to hypoxemia and acidemia in fetal lambs. Am J Obstet Gynecol 120:817-824

7. Yaffe H, Parer JT, Block BS, Llanos AJ 1987 Cardiorespiratory responses to graded reductions of uterine blood flow in the sheep fetus. J Dev Physiol 9:325-336

8. Sheldon RE, Peeters LLH, Jones Jr MD, Makowski EL, Meschia G 1979 Redistribution of cardiac output and oxygen delivery in the hypoxemic fetal lamb. Am J Obstet Gynecol 135:1071-1078

9. Bristow J, Rudolph AM, Itskovitz J, Barnes R 1983 Hepatic oxygen and glucose metabolism in the fetal lamb. $J$ Clin Invest 71:1047-1061

10. Rudolph AM, Heymann MA 1970 Circulatory changes during growth in the fetal lamb. Circ Res 26:289-299

11. Dawes GS, Lewis BV, Milligan JE, Roach MR, Talner NS 1968 Vasomotor responses in the hind limbs of foetal and new-born lambs to asphyxia and aortic chemoreceptor stimulation. J Physiol (Lond) 195:55-81

12. Wilkening RB, Meschia G 1983 Fetal oxygen uptake, oxygenation, and acidbase balance as a function of uterine blood flow. Am J Physiol 244:H749H755

13. Wilkening RB, Boyle DW, Meschia G 1988 Measurement of blood flow and oxygen consumption in the pelvic limb of fetal sheep. Proc Soc Exp Biol Med 187:498-505

14. Wilkening RB, Molina RD, Battaglia FC, Meschia G 1987 Effect of insulin on glucose/oxygen and lactate/oxygen quotients across the hindlimb of fetal lambs. Biol Neonate 51:18-23

15. Cole JWL, Grizzle JE 1966 Applications of multivariate analysis of variance to repeated measurements experiments. Biometrics 22:810-826

16. SAS Institute Inc 1985 SAS User's Guide: Statistics, Version 5 Edition. SAS Institute Inc, Cary, NC

17. Reuss ML, Parer JT, Harris JL, Krueger TR 1982 Hemodynamic effects of alpha-adrenergic blockade during hypoxia in fetal sheep. Am J Obstet Gynecol 142:410-415

18. Rurak DW 1978 Plasma vasopressin levels during hypoxaemia and the cardiovascular effects of exogenous vasopressin in foetal and adult sheep. J Physiol (Lond) 277:341-357

19. Iwamoto HS, Rudolph AM, Keil LC, Heymann MA 1979 Hemodynamic responses of the sheep fetus to vasopressin infusion. Circ Res 44:430-436

20. Perez R, Espinoza M, Riquelme R, Parer JT, Llanos AJ 1989 Arginine vasopressin mediates cardiovascular responses to hypoxemia in fetal sheep. Am J Physiol 256:R1011-R1018

21. Skillman CA, Plessinger MA, Woods JR, Clark KE 1985 Effect of graded reductions in uteroplacental blood flow on the fetal lamb. Am J Physiol 249:H1098-H1105

22. Jones Jr MD, Sheldon RE, Peeters LL, Makowski EL, Meschia G 1978 Regulation of cerebral blood flow in the ovine fetus. Am J Physiol 235: H162H166 